\title{
The Potential of Biogas; The Solution to Energy Storage
}

Villadsen, Sebastian N. B. ; Fosbøl, Philip L.; Angelidaki, Irini; Woodley, John M.; Nielsen, Lars P.; Møller, Per

\section{Published in:}

ChemSusChem

Link to article, DOI:

$10.1002 /$ cssc. 201900100

Publication date:

2019

Document Version

Peer reviewed version

Link back to DTU Orbit

Citation (APA):

Villadsen, S. N. B., Fosbøl, P. L., Angelidaki, I., Woodley, J. M., Nielsen, L. P., \& Møller, P. (2019). The Potential of Biogas; The Solution to Energy Storage. ChemSusChem, 12(10), 2147-2153.

https://doi.org/10.1002/cssc.201900100

\section{General rights}

Copyright and moral rights for the publications made accessible in the public portal are retained by the authors and/or other copyright owners and it is a condition of accessing publications that users recognise and abide by the legal requirements associated with these rights.

- Users may download and print one copy of any publication from the public portal for the purpose of private study or research.

- You may not further distribute the material or use it for any profit-making activity or commercial gain

- You may freely distribute the URL identifying the publication in the public portal 


\section{The Potential of Biogas; The Solution to Energy Storage}

\author{
Sebastian N. B. Villadsen*[a], Philip L. Fosbø|[b], \\ Irini Angelidaki[c], John M. Woodley ${ }^{[b]}$, Lars P. \\ Nielsen ${ }^{[\mathrm{d}]}$ and Per Møller ${ }^{[\mathrm{a}]}$
}

\begin{abstract}
Energy storage will be a demand for balancing the renewable energy systems of tomorrow - especially when excess electricity from wind and solar power requires immediate utilization. Using biogas as a carbon source can generate $\mathrm{CO}_{2}$-neutral carbonbased energy carriers, such as methane or methanol. Utilization of biogas today is limited to the generation of heat and power or biomethane (first generation upgrading), both processes disregarding the potential of the large amount of co-produced $\mathrm{CO}_{2}$ during the fermentation process. Using renewable energy, biogas upgrading systems can convert the carbon dioxide to hydrocarbon-based highdensity energy fuels which can replace fossil-based fuels for applications where they are hard to decarbonize. Here, the authors argue for future utilization possibilities of biogas and introduce the terminology of second generation upgrading to help research and development within this field. We believe that second generation upgrading of biogas will have a huge potential for dynamic energy storage.
\end{abstract}

\section{Biogas}

The market share of renewable energy resources is increasing [1]. Especially wind and solar power has increased tenfold globally from 2004 to 2014 [2]. Consequently, energy storage has become a growing challenge [3]. Several technologies have been proposed to assist in the need for energy storage, e.g. pumped storage hydroelectricity, compressed air energy storage, swing wheel storage, large scale batteries, etc. [4]. Nevertheless, efficient energy storage still remains a huge issue.

\footnotetext{
[a] S. N. B. Villadsen, Prof. P. Møller

Section of Materials and Surface Engineering

Department of Mechanical

Technical University of Denmark

Anker Engelunds Vej 1, 2820 Kgs. Lyngby, Denmark

snbv@mek.dtu.dk

[b] Assoc. Prof. P. L. Fosbøl, Prof. J. Woodley

Department of Chemical and Biochemical Engineering

Technical University of Denmark

Anker Engelunds Vej 1, 2820 Kgs. Lyngby, Denmark

[c] Ph.d. HD(O) L. P. Nielsen

Materials and surface technology

Technological Institute

Kongsvang Allé 29, 8000 Aarhus C, Denmark

[d] Prof. I. Angelidaki

Department of Environmental Engineering

Technical University of Denmark

Anker Engelunds Vej 1, 2820 Kgs. Lyngby, Denmark
}

Biogas has the potential to become the preferred solution to energy storage of the future. Biogas is produced from anaerobic breakdown of different biological feedstocks and generally consists of around $60 \%$ methane $\left(\mathrm{CH}_{4}\right)$ and $40 \%$ carbon dioxide $\left(\mathrm{CO}_{2}\right)$, with approximately $2000 \mathrm{ppm}$ hydrogen sulphide $\left(\mathrm{H}_{2} \mathrm{~S}\right)$ as the main impurity. Independent of the downstream application of biogas, it is necessary to remove $\mathrm{H}_{2} \mathrm{~S}$ due to the corrosion and health issues involved. The majority of biogas plants produce combined heat and power (CHP), while a very small number (around $2 \%$ of all plants) produce biomethane [5]. For biomethane production, the $\mathrm{CO}_{2}$ has to be removed from the biogas in order to ensure a high enough energy density in order to allow for injection in the natural gas grid. This is called biogas upgrading and $\mathrm{CO}_{2}$ is a waste product from this process.

Future biogas upgrading technologies will need to consider $\mathrm{CO}_{2}$ in biogas as an additional carbon source which could be used to increase the energy density in connection with efficient energy storage. In this way, electrical energy could be stored as either methane or liquid organic molecules through catalytic upgrading using renewable hydrogen $\left(\mathrm{H}_{2}\right)$ from electrolysis converting $\mathrm{CO}_{2}$ into liquid fuel through e.g. Fischer-Tropsch-like processes.

Within the EU alone, the biogas energy production was $654 \mathrm{PJ}$ in 2015 [6] and it continues to grow [5]. The biogas energy potential within Europa is estimated to be as high as $2.3 \times 10^{3} \mathrm{PJ}$ by 2030 [6]. This corresponds to $15 \%$ of the total energy used for transportation in the EU in 2015 [7], and if the biogas is further upgraded using renewable $\mathrm{H}_{2}$, this share could be even higher. We believe that the use of biogas can be a key enabler when it comes to closing the carbon cycle. This would allow industries like e.g. aviation and long distance transport [8-10], which are not easily decarbonized, to convert into a sustainably future operating on green carbon-neutral fuel resources. However, these future applications of biogas lack a general term, and we therefore propose to use the term 'second generation upgrading' to describe those technologies, which use the $\mathrm{CO}_{2}$ in biogas as the carbon source.

\section{Upgrading Today; First Generation Upgrading}

Today, biogas upgrading refers to the process of extracting $\mathrm{CH}_{4}$ (biomethane) from biogas $[11,12]$. This process is necessary in order to make biogas suitable as a fuel for vehicles or injection into the natural gas grid [13]. Biomethane is known for its low carbon footprint, which can even be negative [14], making it highly attractive for several industries, such as the agricultural sector, the chemical industry, etc. Today, an industrial upgrading of biogas is solely first generation. The four main first generation upgrading technologies are [15]:

- Chemical scrubbing

- Water scrubbing

- Membrane separation

- Pressure swing adsorption

There are other emerging technologies, however, the above four are the market drivers. 
First generation upgrading seeks to remove $\mathrm{CO}_{2}$ as a waste product, although efforts are being made to create high-valuable food products from $\mathrm{CO}_{2}$, using chemical scrubbing. The $\mathrm{CO}_{2}$ could also be used for energy storage by combining it with hydrogen from electrolysis driven by renewable electricity from wind or solar power. Unfortunately, chemical scrubbing is quite energy intensive and there is no need to use a pure $\mathrm{CO}_{2}$ stream in order to convert it to synthetic hydrocarbon when upgrading biogas. Removing the need for chemical scrubbing would significantly improve the overall energy efficiency of existing biogas upgrading systems [16].

\section{First vs. Second Generation Upgrading}

We believe the time has come to introduce the term 'second generation' upgrading as an alternative to 'first generation' upgrading that exists today.

Second generation upgrading refers to those technologies that utilize the biogas as a carbon source for storing energy. First generation upgrading uses methods, which only focus on the removal of $\mathrm{CO}_{2}$ from biogas, while second generation upgrading technologies actively use the $\mathrm{CO}_{2}$ to produce more carboncontaining energy carriers.

While the two generations of biogas upgrading have several differences of technical and scientific nature, the most efficient distinction between first and second generation biogas upgrading is:

- First generation do not utilize the $\mathrm{CO}_{2}$ of the biogas

- Second generation uses the $\mathrm{CO}_{2}$ as a carbon source

Significant research is being carried out into second generation biogas upgrading [17] (according to our terminology), although the current terminology does not allow distinguishing between first and second generation technologies. Moreover, completely different technologies are required for the second generation upgrading. The main differences are listed in the following sections.

\section{$\mathrm{CO}_{2}$ Utilization}

Second generation upgrading makes use of $\mathrm{CO}_{2}$ as an additional carbon source for energy storage. It is closely linked to the Carbon Capture and Utilization (CCU) technology, which is currently highly promoted, as necessary to reach zero- $\mathrm{CO}_{2}$ policies [18]. It has become obvious that renewable energy supply cannot alone fulfil the wish for $\mathrm{C}_{2}$ neutral society, and therefore, renewable energy should be supplemented by $\mathrm{CO}_{2}$ storage or reuse of the $\mathrm{CO}_{2}$ activities. $\mathrm{CCU}$ allows for a lowering of the carbon footprint to a certain extent with the need to use additional energy running the overall process.

Conversely, second generation biogas upgrading does not require energy-expensive carbon capture. The $\mathrm{CO}_{2}$ in biogas is directly converted to hydrogen-carbon-containing molecules enabling a better overall energy efficiency [16].

\section{Maturity of the Second Generation Upgrading Technology}

In our view, the current terminology on biogas upgrading constrains the economic support by favoring the simpler first generation technology. A new terminology would allow for a more clear focus on the energy storage possibilities of biogas and could help accelerate additional and necessary research and development in second generation upgrading technologies.

First generation upgrading is in use today, whereas second generation upgrading technologies remain in the demonstration phase. There is a clear need for innovative and cost-efficient technology development in second generation upgrading as it requires more expensive and complicated equipment as compared to first generation upgrading. The most promising technologies for second generation upgrading are discussed below.

\section{Biogas as Carbon Source; Second Generation Upgrading}

The conversion of $\mathrm{CO}_{2}$ to biofuel or further conversion to synthetic fuel through Fischer-Tropsch catalytic synthesis is a research area that receives a great deal of attention [18]. Here, we present catalytic methanisation, methanol synthesis and biological conversion. Methanisation and methanol production are visualized in Figure 1, which shows how today's technology emits $\mathrm{CO}_{2}$, while the application of tomorrow's $2^{\text {nd }}$ generation technology uses energy in the form of $\mathrm{H}_{2}$ to produce biofuels.

Common for all the second generation upgrading technologies discussed here is the need for renewable $\mathrm{H}_{2}$. Renewable $\mathrm{H}_{2}$ is produced by water electrolysis, mainly alkaline [19], and this technology has managed to be developed into a pluck-and-play technology characterized by both high efficiency and quick response time, which are of utmost importance when it comes to storage of renewable energy. While, flexible storage of excess energy as $\mathrm{H}_{2}$ is a possibility, storage of the energy as either $\mathrm{CH}_{4}$ or liquid organic molecules ( $\mathrm{HC}$; hydrocarbons) allows for further utilization of the stored energy within the liquid infrastructures already constructed. $\mathrm{CH}_{4}$ can be stored and distributed in the natural gas grid and liquid organic molecules can be implemented in the transportation infrastructure. These applications also deviate from those of renewable $\mathrm{H}_{2}$, since the energy density of the carbon-based storage is much higher as compared to that of $\mathrm{H}_{2}$ [20]. 


\section{Disconnected | Connected}

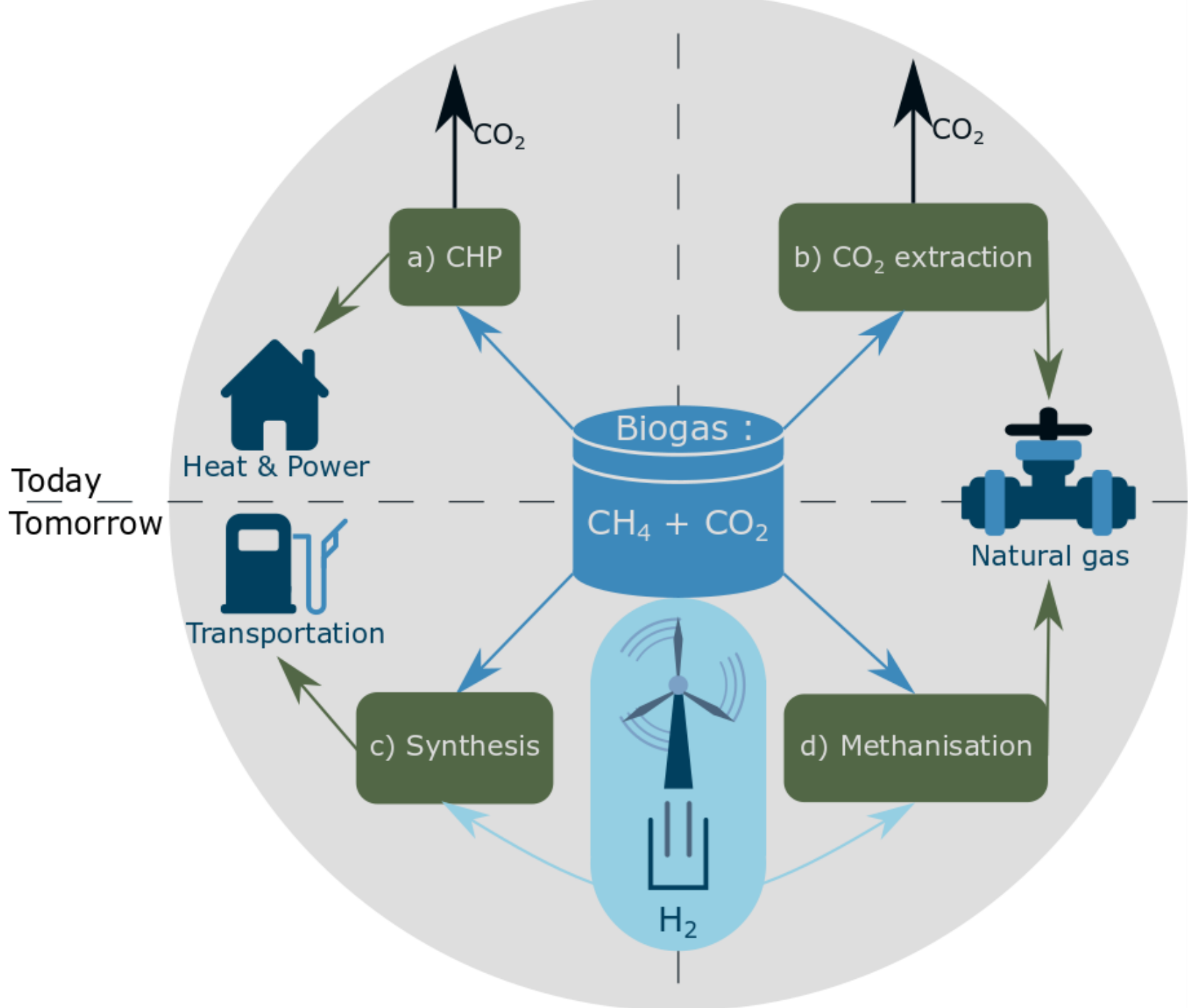

Figure 1: Biogas utilization. a) Combined heat and power system, most widely used application today. b) First generation upgrading, the methane is extracted from the biogas and supplied to the natural gas grid. Both c) and d) are second generation (2D) upgrading technologies, where the biogas is considered a carbon source as the $\mathrm{CO}_{2}$ is converted using renewable hydrogen. c) Synthesis of liquid organic molecules, e.g. methanol, can be used in the transportation sector. d) Methanisation of $\mathrm{CO}_{2}$, allowing energy storage in the natural gas grid

\section{Catalytic Methanisation}

Methanisation of biogas produces $\mathrm{CH}_{4}$ from the $\mathrm{CO}_{2}$ within the raw biogas. The catalytic methanisation process converts the $\mathrm{CO}_{2}$ content to $\mathrm{CH}_{4}$, using the Sabatier reaction:

$\mathrm{CO}_{2}+4 \mathrm{H}_{2} \rightarrow \mathrm{CH}_{4}+2 \mathrm{H}_{2} \mathrm{O} \quad \Delta \mathrm{G}_{300}{ }^{\circ} \mathrm{C}=-61.1 \mathrm{~kJ} / \mathrm{mol}($ eq. 1$)$

This process was first discovered by Sabatier in 1913 and is most notably used today on the international space station to produce water [21]. Traditionally, the reaction is catalyzed over a highsurface-area nickel catalysts having both high selectivity and activity [22]. Desulfurized biogas could be used as a direct feedstock for the Sabatier reaction, since the $\mathrm{CH}_{4}$ will act as an inert diluent which can be beneficial for the exothermic reaction due to its heat-distributing and -absorbent properties avoiding catalyst runaways [23].

The final product of first generation upgrading (biomethane) needs to have a low $\mathrm{H}_{2} \mathrm{~S}$ content. Dependent on the gas grid regulations, the requirement is usually below $4 \mathrm{ppm}$ [24]. For catalytic upgrading, however, the restrictions are far more demanding, since $\mathrm{H}_{2} \mathrm{~S}$ is an irreversible poison for the catalysts used for $\mathrm{CO}_{2}$ reduction $[25,26]$. Bartholomew et al. [27] found that concentrations as low as 1 to $10 \mathrm{ppb} \mathrm{H}_{2} \mathrm{~S}$ may result in considerable reduction of the catalyst activity, since the active 
surface sites react readily with $\mathrm{H}_{2} \mathrm{~S}$, by a deactivation reaction [22]:

$\mathrm{H}_{2} \mathrm{~S}+\mathrm{NiO} \rightarrow \mathrm{NiS}+\mathrm{H}_{2} \mathrm{O} \quad \Delta \mathrm{G}_{300}{ }^{\circ} \mathrm{C}=-48.5 \mathrm{~kJ} / \mathrm{mol}$ (eq. 2)

Thus, the $\mathrm{H}_{2} \mathrm{~S}$ content in the desulphurized biogas should be kept as low as possible for catalytic conversion of biogas in order to achieve a long catalyst lifetime.

Catalytic methanisation is highly suited for energy storage and is driven by hydrogen $\left(\mathrm{H}_{2}\right)$ from renewable energy electrolysis. The $\mathrm{CH}_{4}$ produced is easily stored in the natural gas grid. Much ongoing research is investigating the possibility of implementing catalytic methanisation at biogas plants [28-31]. However, so far only few demonstration plants have been reported $[32,33]$. The largest demonstration plant is the E-gas facility by Audi in Werlte, Germany [34], which operates with the off-gas from a nearby first generation upgrading biogas facility.

\section{Chemoautotrophic Biogas Upgrading}

In a biological upgrading approach, microorganisms use $\mathrm{CO}_{2}$ as the carbon source and reduce it to biomethane. The energy input for this reduction can be provided by reduced compounds such as $\mathrm{H}_{2}$, which provides electrons for the conversion. $\mathrm{H}_{2}$ can be used by archaeal hydrogenotrophic methanogens, which converts it with $\mathrm{CO}_{2}$ to methane. Hence, coupling excess electricity with biomethanation appears to be a very attractive solution.

The biological upgrading approach has several technological advantages compared to thermochemical-based technologies. One of the inherent advantages is that the process occurs at mild temperature conditions (in the range of $30^{\circ} \mathrm{C}$ to $60{ }^{\circ} \mathrm{C}$ i.e. mesophilic or thermophilic) and close to atmospheric pressure. This impacts in a positive way not only with respect to technology safety but also towards the overall economy of biomethanation [35]. Moreover, the process is facilitated by hydrogenotrophic methanogens, which are abundant microorganisms found in biogas plants. Mixed cultures can be used to facilitate the conversion process, meaning sterile conditions are not required. The chemoautotrophic biogas upgrading methods have been validated at both laboratory and pilot scale.

\section{Photosynthetic Biogas Upgrading}

Another discussed approach is based on the symbiotic interactions between oxygenic photosynthetic, lithoautotrophic and heterotrophic microorganisms (i.e. microalgae and cyanobacteria). Today, these microorganisms represent the only biotechnology organisms capable of simultaneously removing multiple biogas pollutants as e.g. $\mathrm{CO}_{2}, \mathrm{H}_{2} \mathrm{~S}$, etc. [36]. This novel biogas upgrading biotechnology relies on photosynthetically driven fixation of $\mathrm{CO}_{2}$, coupled with the removal of $\mathrm{CO}_{2}$ along with other impurities with in the biogas. Apart from capturing $\mathrm{CO}_{2}$, the produced algal biomass can be used for several other purposes. Moreover, nutrients (N, P) are captured [37,38]. Nevertheless, despite the obvious advantages, this approach still has several unsolved technical challenges and remains in the proof-ofconcept phase. Several projects are currently trying to develop relevant upgrading technologies such as the EU Horizon 2020 funded projects INCOVER and URBIOFIN $[39,40]$. The efficiency and sustainability of these technologies still remain to be shown and especially, to be evaluated under industrial relevant conditions.

In addition to the above mentioned technologies, new emerging technologies are continuously appearing in the $R \& D$ literature. These include fermentative technologies where microorganisms are able to produce dicarboxylic acids by capturing of $\mathrm{CO}_{2}$ along with the conversion of sugars, which provide the reducing equivalents. One very well developed approach is production of biosuccunic acid along with biogas upgrading [41]. Biosuccinic acid is a chemical platform, which has wide range of applications. Today, succinic acid is mainly produced from petrochemicals.

\section{Syngas Conversion to Liquid Organic Molecules}

Another second generation upgrading process would be the conversion of biogas to liquid organic molecules. The process may be divided into two steps: syngas production and synthesis of organic compounds, e.g. methanol. In the first step, the $\mathrm{CH}_{4}$ and $\mathrm{CO}_{2}$ in the biogas is reformed to carbon monoxide (CO) and $\mathrm{H}_{2}$ in a combination of different reforming processes:

Steam reforming:

$\mathrm{CH}_{4}+\mathrm{H}_{2} \mathrm{O} \rightarrow \mathrm{CO}+3 \mathrm{H}_{2}$ $\Delta \mathrm{G}_{850^{\circ} \mathrm{C}}=-57.8 \mathrm{~kJ} / \mathrm{mol}$ (eq. 3)

and

Dry reforming:

$\mathrm{CH}_{4}+\mathrm{CO}_{2} \rightarrow 2 \mathrm{CO}+2 \mathrm{H}_{2} \quad \Delta \mathrm{G}_{850}{ }^{\circ} \mathrm{C}=-58.8 \mathrm{~kJ} / \mathrm{mol}$ (eq. 4 )

Olah and co-workers [42] have tested a similar process for methanol production from pure $\mathrm{CH}_{4}$. Here, the authors combine steam and dry reforming in a 2:1 ratio in a single process called bi-reforming:

$3 \mathrm{CH}_{4}+2 \mathrm{H}_{2} \mathrm{O}+\mathrm{CO}_{2} \rightarrow 4 \mathrm{CO}+8 \mathrm{H}$ $\Delta \mathrm{G}_{8500^{\circ} \mathrm{C}}=-174 \mathrm{~kJ} / \mathrm{mol}$ (eq. 5)

Bi-reforming yields syngas with the correct stoichiometric ratio for methanol production, although, it requires that the $\mathrm{CH}_{4}$ to $\mathrm{CO}_{2}$ ratio to be 3:1. Most biogas plants have a ratio of around 2:1 for the $\mathrm{CH}_{4}$ to $\mathrm{CO}_{2}$ ratio, which does not allow for a direct implementation of the bi-reforming process. Instead, at a 2:1 ratio of steam to dry reforming, the biogas composition is better suited for a 1:1 ratio of $\mathrm{CH}_{4}$ to $\mathrm{CO}_{2}$ :

$2 \mathrm{CH}_{4}+\mathrm{CO}_{2}+\mathrm{H}_{2} \mathrm{O} \rightarrow 3 \mathrm{CO}+5 \mathrm{H}_{2}$ $\Delta \mathrm{G}_{850{ }^{\circ} \mathrm{C}}=-117 \mathrm{~kJ} / \mathrm{mol}$ (eq. 6$)$ 
This process, termed bio-reforming, requires additional $\mathrm{H}_{2}$ in order to obtain the correct stoichiometric ratio between $\mathrm{CO}$ and $\mathrm{H}_{2}$. For methanol synthesis, the required $\mathrm{CO}: \mathrm{H}_{2}$ ratio is $1: 2$ [43]

$\mathrm{CO}+2 \mathrm{H}_{2} \rightarrow \mathrm{CH}_{3} \mathrm{OH}$

$\Delta \mathrm{G}_{250{ }^{\circ} \mathrm{C}}=26.8 \mathrm{~kJ} / \mathrm{mol}($ eq. 7$)$

This will allow for energy storage, similar to the methanisation process, as the $\mathrm{H}_{2}$ added to the synthesis could be produced by wind turbine or solar energy enabling green hydrogen formation through electrolysis.

Like the methanisation process, both steam and dry reforming uses a nickel catalyst [44]. Hence, deep upstream desulphurization is required, as also described for the catalytically methanisation above.

A liquid organic compound, such as methanol, is not only much easier to store as compared to upgraded $\mathrm{CH}_{4}$, it also has a higher commercial value. Today, most of the methanol produced in the world is made from fossil fuel [45], although, biomethanol is already produced by gasification of biomass [46]. The list of applications for low-carbon footprint, organic compounds are many including fuel for airplanes, polymer production, formaldehyde synthesis, etc. [47-49].

\section{Flexible Solution}

Flexibility is essential for effective energy storage. Regularly turning the technology on and off is needed to follow the fluctuations of green electricity based on solar cells and wind turbines. Ideally, the storage system can switch from storing (i.e. using electricity) to producing electricity in much the same way as batteries or hydropower [50]. Second generation biogas upgrading has a different goal, since the main objective is to replace fossil fuels in hard-to-decarbonize applications.

Since biogas production is continuous, the application of the biogas should also be continuous. Nevertheless, not all second generation biogas upgrading technologies have this opportunity. Catalytic methanisation favours continuous operation due to the applied temperatures and will need to shut down if the $\mathrm{H}_{2}$ supply fluctuates or stops. The methanol production, however, opens up for much more flexible production.

As described above, to reach the correct stoichiometric composition of the syngas produced from biogas, additional $\mathrm{H}_{2}$ is required. Should the $\mathrm{H}_{2}$ supply stop, however, the methanol production would not stop, but simply produce less. Under the assumption that the production efficiency does not change, approximately $80 \%$ of the methanol production would remain. In the case of too little hydrogen inflow, the produced methanol would contain an additional amount of $\mathrm{CO}$, which is not desired, and a gas cleaning system would need to be implemented if the methanol production plant was designed in this way. A benefit from continuous production of methanol is the ability to deliver according to contract even though no excess energy is available for hydrogen generation needed in order to reach the optimal $\mathrm{CO}: \mathrm{H}_{2}$ ratio is $1: 2$.

However, for better overall use of the carbon, a more complicated system could be implemented, where the excess carbon is stored. For storage, $\mathrm{CO}_{2}$ would be preferred over $\mathrm{CO}$, and thus $\mathrm{a} \mathrm{CO}_{2}$ capture system upstream of the reforming process may be the best solution. The stored $\mathrm{CO}_{2}$ can then be blended-in with the biogas when storage of electricity is required to increase the methanol production as the $\mathrm{CO}_{2}$ can react with $\mathrm{H}_{2}$ directly to form $\mathrm{CO}$ in the reverse water gas shift reaction:

$\mathrm{CO}_{2}+\mathrm{H}_{2} \rightarrow \mathrm{CO}+\mathrm{H}_{2} \mathrm{O}$

$\Delta \mathrm{G}_{250^{\circ} \mathrm{C}}=19.5 \mathrm{~kJ} / \mathrm{mol}($ eq. 8$)$

Or reacted directly to form methanol [43]:

$\mathrm{CO}_{2}+3 \mathrm{H}_{2} \rightarrow \mathrm{CH}_{3} \mathrm{OH}+\mathrm{H}_{2} \mathrm{O} \quad \Delta \mathrm{G}_{250}{ }^{\circ} \mathrm{C}=46.3 \mathrm{~kJ} / \mathrm{mol}$ (eq. 9 )

A second generation biogas upgrading system for methanol production designed according to these design guidelines would have three modes of operation (see Figure 2):

- $\quad$ Normal mode: The system upgrades all the carbon in the biogas to methanol by adding $\mathrm{H}_{2}$ from electrolysis. Electricity is stored in the additional synthesized methanol.

- Production mode: Storing $\mathrm{CO}_{2}$ for later use. The methanol production is approximately $80 \%$ of normal mode and no electricity is used or stored in the synthesized methanol.

- Power mode: Adding $\mathrm{CO}_{2}$ from the gas storage into biogas for higher methanol yield. Electricity is stored in the additional synthesized methanol production. The methanol production is higher than when running in the normal mode.

This system could have a complete utilization of carbon, a continuous methanol production, and have flexibility in electricity consumption. The ultimate performance would be achieved when combining with additional $\mathrm{CO}_{2}$ sources converting $\mathrm{CO}_{2}$ into methanol instead of letting the $\mathrm{CO}_{2}$ into the atmosphere. 


\section{a) Normal mode}

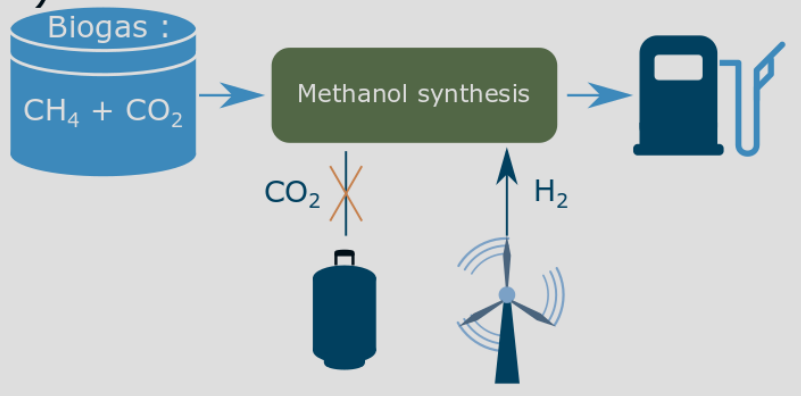

\section{b) Production mode}

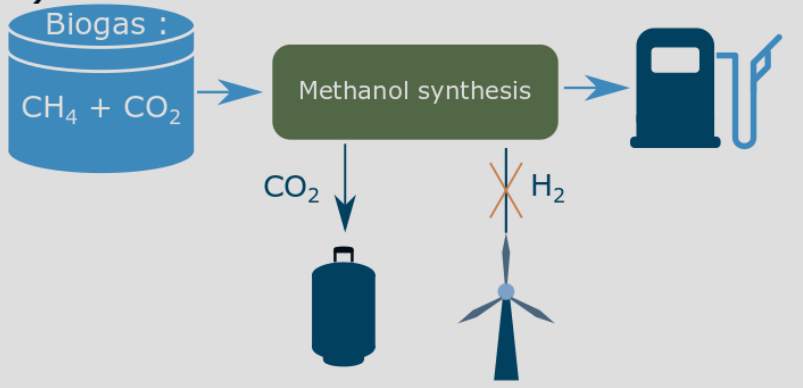

\section{c) Power mode}

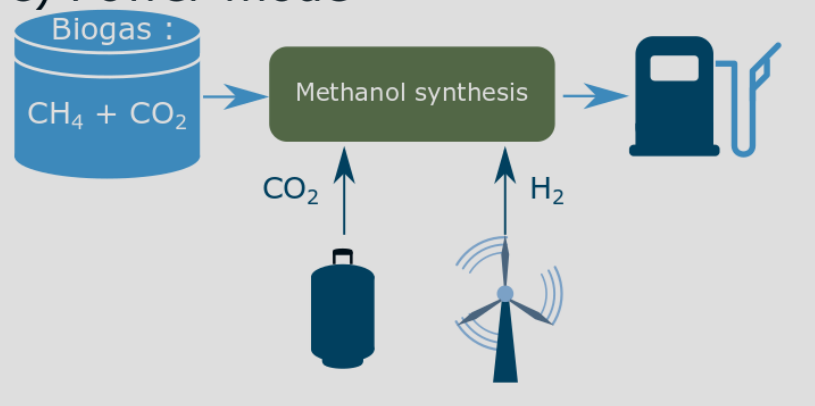

Figure 2: The three different operational modes of the methanol from biogas system. a) Normal operation which will convert the biogas to methanol requiring additional $\mathrm{H}_{2}$ supplied by renewable electrolysis. Energy is stored. b) Production mode is entered when the electricity prices increase due to lack of renewable energy. Instead of adding $\mathrm{H}_{2}, \mathrm{CO}_{2}$ is removed from the biogas and stored while the production continues to operate at approximately $80 \%$ production when compared to normal mode without using electricity. c) Power mode where both $\mathrm{CO}_{2}$ in the biogas and even stored $\mathrm{CO}_{2}$ are converted into methanol. To increase the storing capacity of the system, additional $\mathrm{CO}_{2}$ is added to the biogas, which requires additional $\mathrm{H}_{2}$ for production of methanol. Overall, more energy is stored as methanol, as the production of methanol exceeds that of the normal operational mode.

\section{Outlook}

Biogas is an unusual renewable energy resource with several different aspects:

- Biogas is part of the waste management system. Biological waste can be used directly in the reactor.

- Biogas contributes to a lowering of the carbon footprint enabling green agricultural production.

- Biogas may even be considered a carbon capture technology, as much of the carbon 'caught' in the biogas reactor would otherwise have been emitted to the atmosphere.

Biogas has a lot of unused potential, and could prove central to the interconnected energy infrastructures of the future, as highlighted in Figure 3. Biogas is already a large industry that continues to grow. The upgrading technologies of today, i.e. first generation upgrading, are implemented at a commercial level. Since the market share is increasing, this indicates that the industry is open for new technologies.

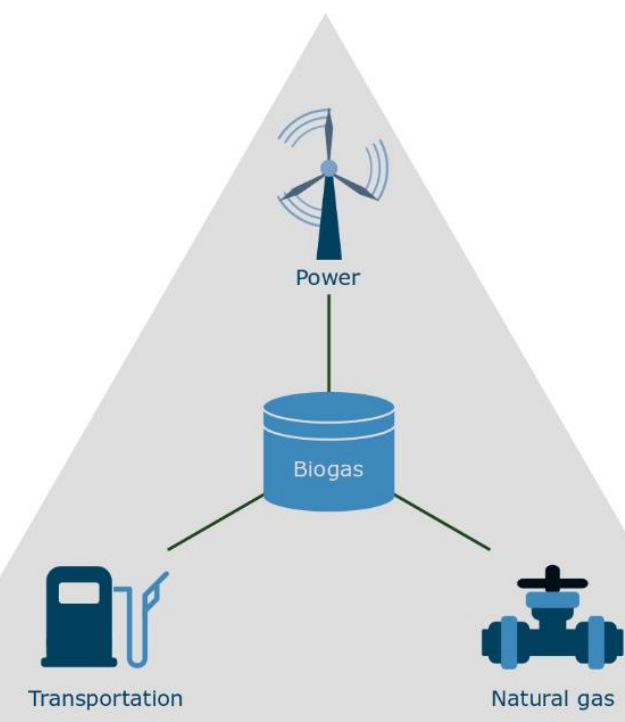

Figure 3: Biogas could be the nexus of three different energy infrastructures. When using biogas for storage of renewable energy, the carbon content allows for utilization both within the natural gas grid and as a versatile fuel in the transportation infrastructure

Using biogas as a medium for energy storage by adding $\mathrm{H}_{2}$ (produced by (green) electrolysis), is receiving interest across Europe, and a few projects are currently researching this idea. The Sabatier reaction, methanol synthesis and biological conversion are today all in use at a commercial level, and although effort has to be made to adapt these technologies to biogas, it should be possible to implement within a relatively short timeframe. 
We believe that a common terminology will help to promote research and development within second generation biogas upgrading. Furthermore, with many of the technologies required for implementation already available, we hope that with this increased promotion, the second generation upgrading could help to ease the green energy transition within 10 years, utilizing upgraded biogas in difficult-to-decarbonize industries.

\section{Acknowledgements}

The authors would like to acknowledge the Danish funding program ForskEL, Project Number 12393.

Keywords: Energy storage and conversion - Environmental chemistry $\bullet$ Biofuels $\bullet$ Sustainable chemistry $\cdot$ Biogas

[1] M. Drechsler, J. Egerer, M. Lange, F. Masurowski, J. Meyerhoff, M. Oehlmann, Efficient and equitable spatial allocation of renewable power plants at the country scale, Nat. Energy. 2 (2017) 17124. doi:10.1038/nenergy.2017.124.

[2] Renewable Energy Policy Network - REN21, Renewables 2015 Global Status Report, 2015. (n.d.). http://www.ren21.net/Portals/0/documents/epaper/GSR2015KF/index.html\#/8 (accessed October 3, 2018).

[3] N. Kittner, F. Lill, D.M. Kammen, Energy storage deployment and innovation for the clean energy transition, 2 (2017) 17125. doi:10.1038/nenergy.2017.125.

[4] D. Lindley, Smart grids: The energy storage problem, Nature. 463 (2010) 18-20. doi:10.1038/463018a.

[5] Biogas - European Biogas AssociationEuropean Biogas Association, (n.d.). http://european-biogas.eu/biogas/ (accessed July 30, 2018)

[6] A.K.P. Meyer, E.A. Ehimen, J.B. Holm-Nielsen, Future European biogas: Animal manure, straw and grass potentials for a sustainable European biogas production, Biomass and Bioenergy. 111 (2018) 154-164. doi:10.1016/j.biombioe.2017.05.013.

[7] EU, Statistical pocketbook 2017 - European Commission, European Union, 2017. https://ec.europa.eu/transport/factsfundings/statistics/pocketbook-2017_en (accessed October 2, 2018).

[8] S.J. Davis, N.S. Lewis, M. Shaner, S. Aggarwal, D. Arent, I.L. Azevedo, S.M. Benson, T. Bradley, J. Brouwer, Y.-M. Chiang, C.T.M. Clack, A. Cohen, S. Doig, J. Edmonds, P. Fennell, C.B. Field, B. Hannegan, B.-M. Hodge, M.I. Hoffert, E. Ingersoll, P. Jaramillo, K.S. Lackner, K.J. Mach, M. Mastrandrea, J. Ogden, P.F. Peterson, D.L. Sanchez, D. Sperling, J. Stagner, J.E. Trancik, C.-J. Yang, K. Caldeira, Net-zero emissions energy systems, Science (80-. ). 360 (2018) eaas9793. doi:10.1126/science.aas9793.

[9] F.S. Zeman, D.W. Keith, Carbon neutral hydrocarbons, (n.d.) doi:10.1098/rsta.2008.0143.

[10] N. Johnson, N. Parker, J. Ogden, How negative can biofuels with CCS take us and at what cost? Refining the economic potential of biofuel production with CCS using spatially-explicit modeling, Energy Procedia. 63 (2014) 6770-6791 doi:10.1016/j.egypro.2014.11.712.

[11] A.S. Nizami, Anaerobic digestion : processes, products, and applications, in: Anaerob. Dig. Process. Prod. Appl., Nova Science Publishers, 2011: pp. 133-147. http://findit.dtu.dk/en/catalog/2417124285 (accessed July 30, 2018).

[12] M. Miltner, A. Makaruk, M. Harasek, Review on available biogas upgrading technologies and innovations towards advanced solutions, J. Clean. Prod. 161 (2017) 1329-1337. doi:10.1016/j.jclepro.2017.06.045.

[13] P.L. Fosbøl, J. Gaspar, B. Jacobsen, J. Glibstrup, A. Gladis, K.M. Diaz, K. Thomsen, J.M. Woodley, N. von Solms, Design and Simulation of Rate-based CO2 Capture Processes Using Carbonic Anhydrase (CA) Applied to Biogas, Energy Procedia. 114 (2017) 1434-1443. doi:10.1016/J.EGYPRO.2017.03.1268.

[14] P. Adams, Chapter 9 - GHG Emissions From Biomethane Gas-toGrid Injection via Anaerobic Digestion, (2018). doi:10.1016/B978-008-101036-5.00009-4.
IEA Bioenergy Task 37, IEA Bioenergy Task 37 - Country Reports Summary 2017, 2018. http://task37.ieabioenergy.com/countryreports.html (accessed October 2, 2018).

[16] D.M. Reiner, Learning through a portfolio of carbon capture and storage demonstration projects, Nat. Energy. 1 (2016) 15011. doi:10.1038/nenergy.2015.11.

[17] M. Bailera, P. Lisbona, L.M. Romeo, S. Espatolero, Power to Gas projects review: Lab, pilot and demo plants for storing renewable energy and CO2, Renew. Sustain. Energy Rev. 69 (2017) 292-312. doi:10.1016/j.rser.2016.11.130.

[18] M. Aresta, A. Dibenedetto, A. Angelini, The changing paradigm in CO2 utilization, J. CO2 Util. 3-4 (2013) 65-73.

doi:10.1016/j.jcou.2013.08.001.

[19] C.K. Kjartansdóttir, L.P. Nielsen, P. Møller, Development of durable and efficient electrodes for large-scale alkaline water electrolysis, Int. J. Hydrogen Energy. 38 (2013) 8221-8231.

doi:10.1016/J.IJHYDENE.2013.04.101.

[20] S.J. Davis, N.S. Lewis, M. Shaner, S. Aggarwal, D. Arent, I.L. Azevedo, S.M. Benson, T. Bradley, J. Brouwer, Y.-M. Chiang, C.T.M. Clack, A. Cohen, S. Doig, J. Edmonds, P. Fennell, C.B. Field, B. Hannegan, B.-M. Hodge, M.I. Hoffert, E. Ingersoll, P. Jaramillo, K.S. Lackner, K.J. Mach, M. Mastrandrea, J. Ogden, P.F Peterson, D.L. Sanchez, D. Sperling, J. Stagner, J.E. Trancik, C.-J. Yang, K. Caldeira, Net-zero emissions energy systems, Science (80-.) . 360 (2018) eaas9793. doi:10.1126/science.aas9793.

[21] Z.W. Greenwood, M.B. Abney, J.L. Perry, L.A. Miller, J. Engineering, R.W. Dahl, N.M. Hadley, S.R. Wambolt, R.R. Wheeler Increased Oxygen Recovery from Sabatier Systems Using Plasma Pyrolysis Technology and Metal Hydride Separation, 2015. https://ntrs.nasa.gov/search.jsp?R=20150016511 (accessed September 27, 2018).

[22] S. Rönsch, J. Schneider, S. Matthischke, M. Schlüter, M. Götz, J. Lefebvre, P. Prabhakaran, S. Bajohr, Review on methanation From fundamentals to current projects, (2016).

doi:10.1016/j.fuel.2015.10.111.

[23] K. Stangeland, D. Kalai, H. Li, Z. Yu, CO 2 Methanation: The Effect of Catalysts and Reaction Conditions, Energy Procedia. 105 (2017) 2022-2027. doi:10.1016/j.egypro.2017.03.577.

[24] L. Yang, X. Ge, C. Wan, F. Yu, Y. Li, Progress and perspectives in converting biogas to transportation fuels, Renew. Sustain. Energy Rev. 40 (2014) 1133-1152. doi:10.1016/j.rser.2014.08.008.

[25] C.H. Bartholomew, Mechanisms of catalyst deactivation, Appl. Catal. A Gen. 212 (2001) 17-60. doi:10.1016/S0926860X(00)00843-7.

[26] K. Müller, M. Fleige, F. Rachow, D. Schmeißer, Sabatier based CO 2-methanation of flue gas emitted by conventional power plants, Energy Procedia. 40 (2013) 240-248.

doi:10.1016/j.egypro.2013.08.028

C.H. Bartholomew, Mechanisms of Nickel Catalyst Poisoning, 34 (1987) 81-104. doi:10.1016/S0167-2991(09)60352-9.

[28] A.C. Faria, C.V. Miguel, L.M. Madeira, Thermodynamic analysis of the $\mathrm{CO} 2$ methanation reaction with in situ water removal for biogas upgrading, J. CO2 Util. 26 (2018) 271-280. doi:10.1016/J.JCOU.2018.05.005

[29] L. Jürgensen, E.A. Ehimen, J. Born, J.B. Holm-Nielsen, Dynamic biogas upgrading based on the Sabatier process: Thermodynamic and dynamic process simulation, Bioresour. Technol. 178 (2015) 323-329. doi:10.1016/j.biortech.2014.10.069.

[30] G. Leonzio, Design and feasibility analysis of a Power-to-Gas plant in Germany, J. Clean. Prod. 162 (2017) 609-623.

doi:10.1016/j.jclepro.2017.05.168.

[31] A. Varone, M. Ferrari, Power to liquid and power to gas: An option for the German Energiewende, Renew. Sustain. Energy Rev. 45 (2015) 207-218. doi:10.1016/J.RSER.2015.01.049.

[32] M. Götz, J. Lefebvre, F. Mörs, A. McDaniel Koch, F. Graf, S. Bajohr R. Reimert, T. Kolb, Renewable Power-to-Gas: A technological and economic review, Renew. Energy. 85 (2016) 1371-1390. doi:10.1016/j.renene.2015.07.066.

[33] S. Brynolf, M. Taljegard, M. Grahn, J. Hansson, Electrofuels for the transport sector: A review of production costs, Renew. Sustain. Energy Rev. 81 (2018) 1887-1905. doi:10.1016/j.rser.2017.05.288. P.F. Tropschuh, E. Pham, Audi Future Energies: Balancing Business and Environmental Concerns, in: Springer, Cham, 2014: pp. 185-190. doi:10.1007/978-3-319-01884-3_18.

[35] I. Angelidaki, L. Treu, P. Tsapekos, G. Luo, S. Campanaro, H. Wenzel, P.G. Kougias, Biogas upgrading and utilization: Current status and perspectives, Biotechnol. Adv. 36 (2018) 452-466. doi:10.1016/j.biotechadv.2018.01.011.

[36] M. Bahr, I. Díaz, A. Dominguez, A. González Sánchez, R. Muñoz, Microalgal-biotechnology as a platform for an integral biogas 
upgrading and nutrient removal from anaerobic effluents, Environ. Sci. Technol. 48 (2014) 573-581. doi:10.1021/es403596m.

[37] J.L. Conde, L.E. Moro, L. Travieso, E.P. Sanchez, a. Leiva, R. Dupeir n, R. Escobedo, Biogas purification process using intensive microalgae cultures, Biotechnol. Lett. 15 (1993) 317-320. doi:10.1007/BF00128326.

[38] G. Mandeno, R. Craggs, C. Tanner, J. Sukias, J. Webster-Brown, Potential biogas scrubbing using a high rate pond, Water Sci. Technol. 51 (2005) 253-256.

[39] Incover | Innovative Eco-Technologies for Ressource Recovery from Wastewater, (n.d.). http://incover-project.eu/ (accessed October 8, 2018).

[40] URBIOFIN Project, (n.d.). https://www.urbiofin.eu/ (accessed October 8, 2018)

[41] I.B. Gunnarsson, M. Alvarado-Morales, I. Angelidaki, Utilization of CO2 Fixating Bacterium Actinobacillus succinogenes $130 \mathrm{Z}$ for Simultaneous Biogas Upgrading and Biosuccinic Acid Production, (2014). doi:10.1021/es504000h.

[42] G.A. Olah, A. Goeppert, M. Czaun, T. Mathew, R.B. May, G.K.S Prakash, Single Step Bi-reforming and Oxidative Bi-reforming of Methane (Natural Gas) with Steam and Carbon Dioxide to Metgas $\left(\mathrm{CO}-2 \mathrm{H}_{2}\right)$ for Methanol Synthesis: Self-Sufficient Effective and Exclusive Oxygenation of Methane to Methanol with Oxygen, J. Am. Chem. Soc. 137 (2015) 8720-8729. doi:10.1021/jacs.5b02029. decomposition, n.d. http://production.datastore.cvt.dk/filestore?oid=548201448c7966ac1 d00098b\&targetid $=548201448 c 7966 a c 1 d 00098 d$ (accessed September 27, 2018).

[44] J.L. Rogers, M.C. Mangarella, A.D. D'amico, J.R. Gallagher, M.R Dutzer, E. Stavitski, J.T. Miller, C. Sievers, Differences in the Nature of Active Sites for Methane Dry Reforming and Methane Steam Reforming over Nickel Aluminate Catalysts, ACS Catal. 6 (2016) 16. doi:10.1021/acscatal.6b01133.

[45] B.A. V. Santos, J.M. Loureiro, A.M. Ribeiro, A.E. Rodrigues, A.F. Cunha, Methanol production by bi-reforming, Can. J. Chem. Eng. 93 (2015) 510-526. doi:10.1002/cjce.22068.

[46] A. Demirbas, Biomethanol Production from Organic Waste Materials, Energy Sources, Part A Recover. Util. Environ. Eff. 30 (2008) 565-572. doi:10.1080/15567030600817167.

[47] D. Lamprecht*, Fischer-Tropsch Fuel for Use by the U.S. Military as Battlefield-Use Fuel of the Future, (2007). doi:10.1021/EF060607M.

[48] I. Tincul, J. Smith, P. van Zyl, Multipolymers with Fischer-Tropsch olefins, Macromol. Symp. 193 (2003) 13-28. doi:10.1002/masy.200390047.

[49] G.A. Olah, A. Goeppert, G.K.S. Prakash, Beyond Oil and Gas: The Methanol Economy, Wiley-VCH Verlag GmbH \& Co. KGaA Weinheim, Germany, 2009. doi:10.1002/9783527627806.

[50] D.E.H.J. Gernaat, P.W. Bogaart, D.P. Van Vuuren, H. Biemans, R. Niessink, High-resolution assessment of global technical and economic hydropower potential, Nat. Energy. (2017). doi:10.1038/s41560-017-0006-y. 


\section{CONCEPT}

We propose biogas as a carbon source for energy storage and argues for the introduction of the terminology 'first' and 'second' generation upgrading to distinguish between upgrading technologies.
Sebastian N. B. Villadsen*, Philip L.

Fosbol, Irini Angelidaki, John M. Woodley, Lars P. Nielsen and Per Møller

Page No. - Page No.

The Potential of Biogas;

The Solution to Energy Storage 